\title{
PERANCANGAN PROTOTYPE ALAT PENDETEKSI KEBOCORAN GAS LPG BERBASIS ARDUINO UNO R3 DENGAN MODUL SIM80OL DAN ESP8266 SEBAGAI MEDIA INFORMASI
}

\author{
Afdhal Eka Kurniawan ${ }^{1}$, Mayda Waruni K. ${ }^{2}$, A. Asni B. ${ }^{3}$ \\ 1,2,3 Teknik Elektro,Fakultas Teknologi Industri Universitas Balikpapan \\ Jln. Pupuk Raya Gn. Bahagia Balikpapan 76114 INDONESIA \\ Email : afdhal.e.kurniawan@gmail.com
}

\begin{abstract}
The LPG (Liquefied Petroleum Gas) gas leak detection and monitoring system is an anticipatory measure for safety from hazards such as gas cylinder explosions. This research aims to build a detection system by integrating MQ-6 sensor, Arduino microcontroller and ESP8266. Data can then be displayed on the Blynk application and notifications will be given via the application and email. The process of sending data using SIM800L module GSM/GPRS is a part that serves to communicate between the main monitors with mobile phone and the module ESP8266E ESP 12E WIFI IOT for data transfer in WIFI network . And this system has fulfilled the rules of the Internet of things, making it easier for the community in its application.
\end{abstract}

Keyword- LPG,Monitoring, Microcontroller , internet of Thing

Intisari-Sistem Pendeteksi dan Monitoring kebocoran gas LPG (Liquefied Petroleum Gas) merupakan sebuah langkah antisipasi untuk keamanan dari bahaya seperti ledakan tabung gas. Penelitian ini bertujuan untuk membangun sebuah sistem pendeteksi dengan mengintegrasikan sensor MQ-6, mikrokontroler Arduino dan ESP8266. Data dapat kemudian ditampilkan pada aplikasi Blynk dan notifikasi akan diberikan melalui aplikasi dan email. Proses pengiriman data menggunakan Modul SIM800L GSM/GPRS adalah bagian yang berfungsi untuk berkomunikasi antara pemantau utama dengan Handphone dan Modul ESP8266E ESP 12E WIFI IOT untuk transfer data dalam jaringan WIFI. Dan sistem ini telah memenuhi kaidah Internet of things, sehingga mempermudah masyarakat dalam pengaplikasiannya.

Kata Kunci-LPG, monitoring, mikrokontroler,Internet of Thing

\section{Pendahuluan}

Perkembangan ilmu pengetahuan dan teknologi yang semakin maju saat ini berdampak pada meningkatnya kebutuhan manusia akan sumber daya energi. Dimana selama ini manusia lebih banyak menggunakan sumber energi yang dihasilkan oleh alam sebagai sumber energi utama. Melalui sumber energi inilah manusia menggunakannya untuk keperluan sehari-hari, termasuk penggunaan LPG (Liquefied Petroleum Gas). Banyak sekali kebutuhan LPG saat ini seperti digunakan untuk keperluan dapur, LPG juga bisa digunakan sebagai bahan bakar kendaraan bermotor atau yang biasa disebut BBG (Bahan Bakar Gas).

Pertamina memperkirakan kebutuhan LPG tahun ini sebanyak 7 juta metrik ton. Sementara produksi LPG di dalam negeri masih sekitar 50 ton sampai 70 ton per hari untuk setiap kilang LPG. Jadi, sebanyak 65 persen dari kebutuhan domestik bersumber dari impor. konsumsi masyarakat Indonesia terhadap penggunaan gas LPG. [1]

Namun dari banyak kelebihan yang bisa didapatkan dari pemanfaatan LPG, perlu di perhatikan juga beberapa faktor berbahaya yang harus diwaspadai. Seperti proses pemasangan tabung LPG yang tidak benar dapat menyebabkan terjadinya kebocoran gas yang nantinya dapat memicu ledakan. [2].

Dari masalah diatas, penulis tertarik untuk melakukan sebuah penelitian dengan judul PERANCANGAN PROTOTYPE ALAT PENDETEKSI KEBOCORAN GAS LPG BERBASIS ARDUINO UNO R3 DENGAN MODUL SIM800L DAN ESP8266 SEBAGAI MEDIA INFORMASI.

\section{LANDASAN TEORI}

Penelitian akan dimulai dengan proses perancangan alat pendeteksi kebocoran gas LPG berbasis arduino uno. Secara keseluruhan sistem terdiri dari input, proses dan output. Yang mana Input adalah sensor MQ-6. Proses adalah Mikrokontroler Arduino dan output adalah LED, Buzzer.

\section{1) $L P G$}

LPG merupakan gas hidrokarbon produksi dari kilang minyak dan kilang gas dengan komponen utama gas propane dan butane dan dikemas didalam tabung. Di Indonesia, LPG digunakan terutama sebagai bahan bakar untuk memasak. Konsumen LPG bervariasi, mulai dari rumah tangga, kalangan komersial (restoran, hotel) hingga industri. . Sejak tahun 2007, pemerintah menggulirkan program Konversi Minyak Tanah ke LPG, dengan tujuan untuk mengubah pengguna minyak tanah bersubsidi yang mayoritas merupakan kalangan masyarakat ekonomi lemah menjadi pengguna LPG. [6]

\section{2) Arduino Uno R3}

Arduino Uno merupakan pengendali mikro single-board yang bersifat open-source, diturunkan dari Wiring platform, dirancang untuk memudahkan pengguna elektonik dalam berbagai bidang. Hardawarenya memiliki prosesor Atmel AVR dan Softwarenya memiliki bahasa pemrograman sendiri. Arduino adalah kit mikrokontroler yang serba bisa dan sangat mudah penggunaannya. Untuk membuatnya diperlukan chip 
programer (untuk menanamkan bootloader Arduino pada chip). [7]

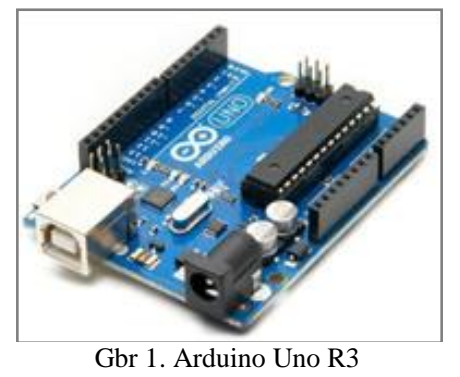

Arduino Uno didasarkan pada Atmega328 (datasheet). Arduino Uno mempunyai 14 pin digital input/output (6 diantaranya dapat digunakan sebagai output PWM), 6 inout analog sebuah osilator Kristal $16 \mathrm{MHz}$, sebuah koneksi USB, sebuah power jack, sebuah ICSP header, dan mikrokontroler, mudah menghubungkannya ke sebuah komputer dengan sebuah kabel USB atau mensuplaynya dengan sebuah adaptor AC ke DC atau menggunakan baterai untuk memulainya. Berikut adalah spesifikasi Arduino Uno R3. [8]

\section{3) Sensor Gas MQ-6}

MQ-6 adalah Sensor gas yang digunakan untuk mendeteksi lpg, Iso-butane, Propane dengan sensitivitas yang tinggi.

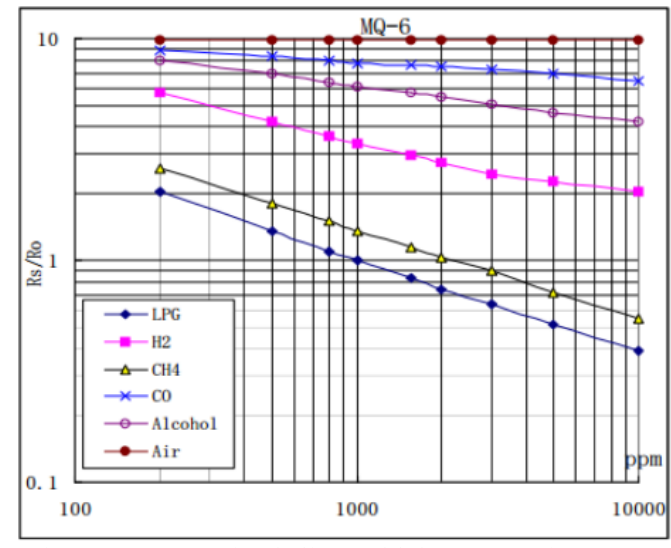

Gbr 2. Kurva Karakteristik Sensitivitas MQ-6 dengan gas

Kurva ini menunjukkan kesensitivitas dari sensor MQ-6 terhadap gas LPG, H2, CH4, CO, Alkohol, air. Pada Suhu: $20{ }^{\circ} \mathrm{C}$, Kelembaban: $65 \%$, Konsentrasi O2 21\%, RL $=20 \mathrm{k} \Omega$, Ro: resistansi sensor pada 1000 ppm LPG di udara bersih. Rs: resistansi sensor pada berbagai konsentrasi gas. [9]

\section{4) RGB KY-016 Color LED}

Lampu RGB LED adalah lampu LED yang bisa memancarkan 3 warna cahaya dalam satu unit Led secara bergantian, dinamakan RGB adalah karena singkatan dari 3 warna dalam bahasa Inggris yaitu $R=\operatorname{Red}, G=$ Green dan $B=$ Blue. Cahaya yang dipancarkan oleh RGB LED sangat menarik sekali, karena cahaya tersebut dapat memancarkan secara bergantian tanpa menggunakan rangkaian elektronik tambahan. Diameter LED 5mm, 2.25 - 3V max, 20mA, Temperatur -30C +85 C. [10]

\section{5) Buzzer}

Buzzer adalah sebuah komponen elektronika yang berfungsi untuk mengubah getaran listrik menjadi getaran suara. Pada dasarnya prinsip kerja buzzer adalah kumparan yang terpasang pada diafragma dan kemudian kumparan tersebut dialiri arus sehingga menjadi elektromagnet, kumparan tadi akan tertarik ke dalam atau keluar, tergantung dari arah arus dan polaritas magnetnya, karena kumparan dipasang pada diafragma maka setiap gerakan kumparan akan menggerakkan diafragma secara bolak-balik sehingga membuat udara bergetar yang akan menghasilkan suara.

\section{6) LCD (Liquid Crystal Display)}

LCD (Liquid Crystal Dispalay) sering diartikan dalam bahasa indonesia sebagai tampilan kristal cair merupakan suatu jenis media tampilan yang menggunakan kristal cair sebagai penampil utama. Salah satu LCD yang sering dipergunakan adalah LCD 16x2 artinya LCD tersebut terdiri dari 16 kolom dan 2 baris. LCD sering digunakan karena harganya relatif murah dan pemakaiannya yang mudah. [4]

\section{7) Modem SIM800L}

SIM800L adalah modul SIM yang digunakan pada penelitian ini. Modul SIM800L GSM/GPRS adalah bagian yang berfungsi untuk berkomunikasi antara pemantau utama dengan Handphone. ATCommand adalah perintah yang dapat diberikan modem GSM/CDMA seperti untuk mengirim dan menerima data berbasis GSM/GPRS, atau mengirim dan menerima SMS. SIM800L GSM/GPRS dikendalikan melalui perintah AT.

SMS atau Short Messaging System adalah pengiriman SMS dari dan ke PC perlu dilakukan terlebih dahulu koneksi ke SMSC. Koneksi PC ke SMSC adalah dengan menggunakan terminal berupa GSM modem ataupun ponsel yang terhubung dengan PC. Dengan menggunakan ponsel, SMS yang mengalir dari atau ke SMSC harus berbentuk PDU (Protocol Data Unit). PDU berisi bilangan - bilangan heksadesimal yang mencerminkan bahasa I/O (kode). PDU sendiri terdiri atas beberapa bagian yang berbeda antara mengirim dan menerima SMS dari SMSC. Format data PDU ini dikirimkan ke PC dalam bentuk teks (string) yang menunjukkan nilai heksadesimalnya. Jadi saat ponsel mengirim data heksadesimal F $(0 \mathrm{FH})$, maka yang diterima oleh PC adalah teks F. [11]

\section{8) Modul ESP8266E ESP 12E WIFI IOT}

Modul ESP8266 merupakan SoC (System on Chip) dengan stack protocol TCP/IP yang telah terintegrasi, sehingga mudah di akses menggunakan mikrokontroler melalui komunikasi serial 802.11 b/g/n Wi-Fi Direct (P2P). Modul Wi-Fi ESP8266 dapat berfungsi sebagai host maupun sebagai modul transfer data dalam jaringan Wi-Fi . [12]

Modul ini memiliki kemampuan pengolahan dan penyimpanan data yang baik sehingga memungkinkan untuk diintegrasikan dengan sensor dan perangkat khusus lainnya melalui GPIO. Hingga saat ini ESP8266 memiliki banyak varian yang telah beredar juga banyak pabrikan yang telah 
membuat modul - modul berbasis ESP8266 hingga yang terbaru adalah jenis NodeMcu. Dari sekian banyak varian ESP8266, dalam penelitian ini akan dibahas mengenai ESP-01, ESP-01 hanya memiliki 8 pin kaki.

Tethering memiliki arti untuk membagi atau sharing koneksi internet dari sebuah perangkat mobile dengan perangkat lain. Sharing koneksi internet tersebut bisa dilakukan melaui Wifi atau wireless LAN, Bluetooth atau menggunakan koneksi fisik dengan menggunakan kabel. [13]

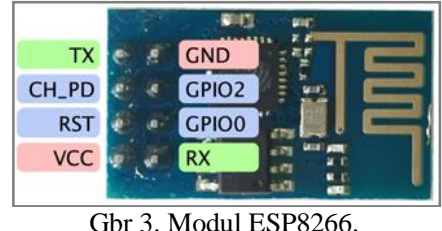

\section{9) Internet of Things}

Internet of Things, atau dikenal juga dengan singkatan IoT, merupakan sebuah konsep yang bertujuan untuk memperluas manfaat dari konektivitas internet yang tersambung secara terus-menerus. Adapun kemampuan seperti berbagi data, remote control, dan sebagainya, termasuk juga pada benda di dunia nyata. Contohnya bahan pangan, elektronik, koleksi, peralatan apa saja, termasuk benda hidup yang semuanya tersambung ke jaringan lokal dan global melalui sensor yang tertanam dan selalu aktif.

Pada dasarnya, Internet of Things mengacu pada benda yang dapat diidentifikasikan secara unik sebagai representasi virtual dalam struktur berbasis Internet. Istilah Internet of Things awalnya disarankan oleh Kevin Ashton pada tahun 1999 dan mulai terkenal melalui Auto-ID Center di MIT. [14]

\section{0) Aplikasi Blynk}

Blynk adalah aplikasi untuk iOS dan OS Android untuk mengontrol Arduino,NodeMCU,Raspberry Pi dan sejenisnya melalui Internet. Aplikasi ini dapat digunakan untuk mengendalikan perangkat hardware,menampilkan data sensor, menyimpan data,visualisasi, dan lain-lain. Aplikasi Blynk memiliki 3 komponen utama.yaitu Aplikasi, Server, dan Libraries. Blynk server berfungsi untuk menangani semua komunikasi diantara smartphone dan hardware. Widget yang tersedia pada Blynk diantaranya adalah Button, Value Display, History Graph, Twitter, dan Email. Blynk tidak terikat dengan beberapa jenis microcontroller namun harus didukung hardware yang dipilih. NodeMCU dikontrol dengan Internet melalui WiFi,chip ESP8266, Blynk akan dibuat online dan siap untuk Internet of Things. [15]

\section{METODE PENELITIAN}

\section{A. Jalannya penelitian}

Penelitian akan dimulai dengan proses perancangan alat pendeteksi kebocoran gas LPG berbasis arduino uno. Secara keseluruhan sistem terdiri dari input, proses dan output. Yang mana Input adalah sensor MQ-6. Proses adalah Mikrokontroler Arduino dan output adalah LED, Buzzer.

Blok diagram merupakan gambaran atau bagan yang memperlihatkan urutan dan hubungan antara proses satu dengan yang lain beserta instruksi didalamnya. Blok diagram yang digambarkan digunakan untuk memahami gambaran dari alat yang dibuat secara umum, untuk menyelesaikan suatu permasalahan atau merepresentasikan proses yang dibuat. Adapun blok diagram dapat dilihat pada gambar di bawah ini.

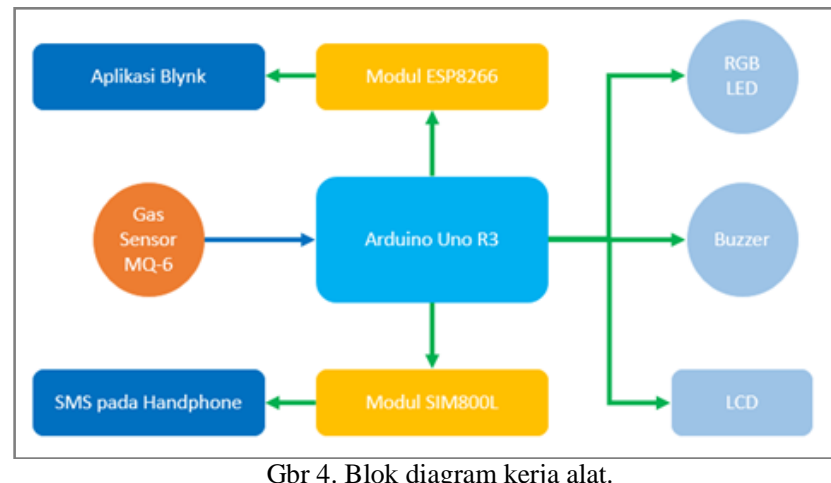

Berdasarkan diagram blok di atas dapat dijelaskan secara garis besar prinsip kerja alat pendeteksi kebocoran gas berbasis arduino uno dengan media informasi SIM800L dan ESP8266 :

1) Ketika alat dinyalakan pertama kali akan dilakukan pemeriksaan terhadap modul RGB LED akan menyala hijau. maka Sensor MQ-6 akan memberikan sinyal analog ke Arduino melalui pin Input Analog.

3) Selanjutnya sinyal analog tersebut di ubah menjadi sinyal digital oleh converter yang ada pada Arduino sehingga sinyal tersebut dapat di proses sesuai dengan logika program.

4) Kemudian mikrokontroler arduino akan memberikan perintah pada RGB LED untuk berubah menjadi merah, Buzzer untuk aktif (On) sesuai dengan logika pada program saat kadar gas LPG teridentifikasi 50\%. LED disini berfungsi sebagai indikator, Buzzer sebagai alarm. Modul SIM800L berfungsi memberikan data kadar gas dan juga sebagai indikator melalui sms jika kadar gas LPG dalam ruangan.

5) Modul ESP8266 diperlukan untuk memonitor kadar gas secara real time melalui aplikasi Blynk dan notifikasi email ke pada pengguna saat terdeteksi kebocoran gas LPG.

Dari diagram alir di bawah dapat diketahui proses kerja alat pendeteksi kebocoran tabung gas LPG berbasis arduino yang dirancang, yaitu :

1) Dimana saat tidak terdeteksi kandungan gas LPG diudara maka RGB LED akan menyala hijau, LCD akan menunjukkan "Normal" dan ESP8266 akan mengirimkan data kandungan gas.

2) Saat terdeteksi kandungan gas LPG $>=30 \%$ maka RGB LED akan menyala merah, buzzer akan aktif, SIM800L akan mengirimkan pesan kepada pengguna, LCD akan menunjukkan data kandungan gas dan ESP8266 mengirimkan email dan notifikasi pada handphone pengguna.

Komponen elektronik rancang sesuai dengan rangkaian yang digunakan. Kemudian rangkaian tersebut diuji coba untuk 
mengetahui apakah rangkaian tersebut sudah terhubung dan bekerja dengan benar. Analisis singkat tentang cara kerja pada rangkaian alat pendeteksi kebocoran gas menggunakan arduino uno dengan modul SIM800L sebagai notifikasi dan modul ESP8266 sebagai koneksi untuk realtime monitoring

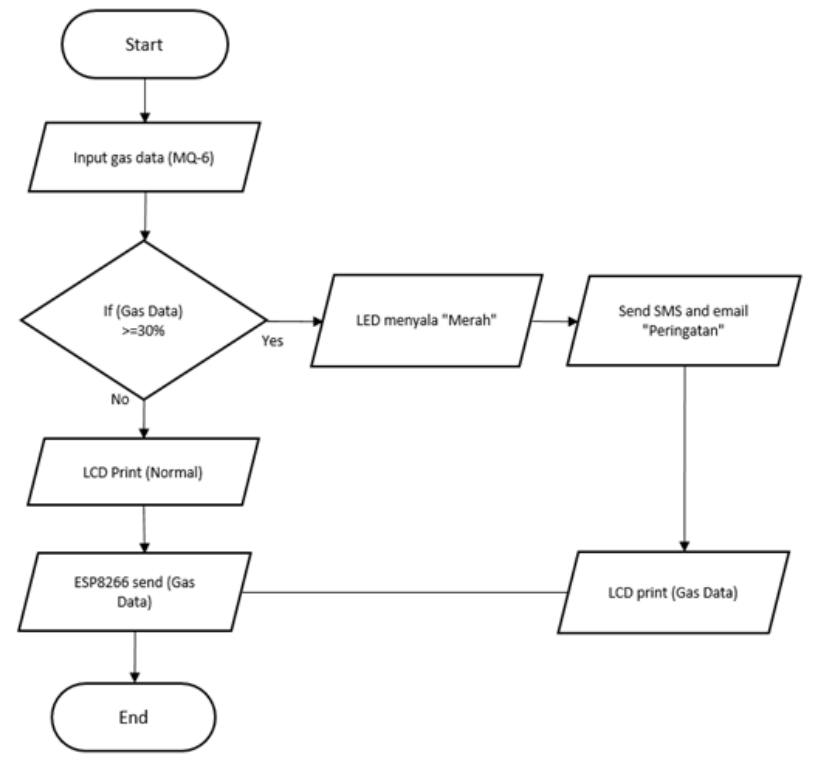

Gbr 5. Diagram alir kerja alat.

B. Instrumentasi penelitian

TABEL I : ALAT DAN BAHAN

\begin{tabular}{|l|c|l|}
\hline \multicolumn{1}{|c|}{ Nama Komponen } & Jumlah & \multicolumn{1}{c|}{ Fungsi Pada Alat } \\
\hline Arduino Uno R3 & 1 & Pengendali utama kerja alat \\
\hline Sensor gas MQ-6 & 1 & $\begin{array}{l}\text { Pendeteksi kandungan gas LPG } \\
\text { dalam udara }\end{array}$ \\
\hline RGB Led & 1 & $\begin{array}{l}\text { Peringatan bahaya kebocoran gas } \\
\text { secara visual berdasarkan warna } \\
\text { lampu }\end{array}$ \\
\hline LCD & 1 & $\begin{array}{l}\text { Sebagai penunjuk parameter } \\
\text { operasi alat }\end{array}$ \\
\hline Buzzer & 1 & $\begin{array}{l}\text { Peringatan bahaya kebocoran gas } \\
\text { melalui audio }\end{array}$ \\
\hline Modul SIM800L & 1 & $\begin{array}{l}\text { Peringatan bahaya kebocoran gas } \\
\text { melalui pesan singkat pada } \\
\text { handphone }\end{array}$ \\
\hline Modul WIFI ESP8266 & 1 & $\begin{array}{l}\text { Koneksi antara arduino dengan } \\
\text { sistem monitoring secara real time } \\
\text { melalui aplikasi web }\end{array}$ \\
\hline Laptop/handphone & 1 & $\begin{array}{l}\text { Melakukan proses pengamatan } \\
\text { kandungan gas LPG via Blynk }\end{array}$ \\
\hline
\end{tabular}

C. Metode pengumpulan data

Proses pengumpulan data dilakukan dalam 3 kategori langkah, yaitu :

1) Studi Literatur

Penyusunan dasar teori yang peneliti gunakan selama proses perancangan prototype pendeteksi kebocoran gas yang berbasis arduino uno adalah mengambil referensi utama yang bersumber dari jurnal ilmiah dan internet. Tujuan utama peneliti dalam melakukan studi literatur ini adalah penetili dapat mengidentifikasi variabel yang akan diteliti. Dalam hal ini variabel yang dimaksud adalah komponen dasar yang akan digunakan dalam pemodelan maupun perancangan prototype pendeteksi kebocoran gas berbasis arduino uno.

2) Metode Experimental

Metode experimental adalah penelitian yang dilakukan dengan cara melakukan uji coba dimana rancangan elektronika untuk komponen hardware alat dan sistem pendeteksi kebocoran gas dapat bekerja sesuai dengan tujuan dan target yang dinginkan.

3) Analisa Kebutuhan

Setelah melakukan analisa komponen apa saja yang akan dibutuhkan untuk membuat alat tersebut. Kemudian mencari referensi dari beberapa sumber setelah memahami, peneliti mulai mempersiapkan perangkat - perangkat yang digunakan seperti: jenis Mikrokontroler, jenis Sensor, Modem GSM dan WIFI.

\section{IV.HASIL DAN PEMBAHASAN}

Pengujian alat dilakukan untuk mengambil data-data hasil perancangan yang digunakan sebagai acuan untuk analisis perancangan sistem.

Gas sensor MQ-6 dikoneksikan dengan arduino uno dan dilakukan penelitian terhadap nilai pembacaan sensor saat tidak adanya gas LPG di udara. Pengujian ini bertujuan untuk mengetahui apakah rangkaian sensor gas dapat mendeteksi adanya kebocoran gas yang berada diruangan.

Pengkodean dilakukan menggunakan arduino ide, berikut ini adalah source code dari untuk sensor gas MQ-6 pada arduino.

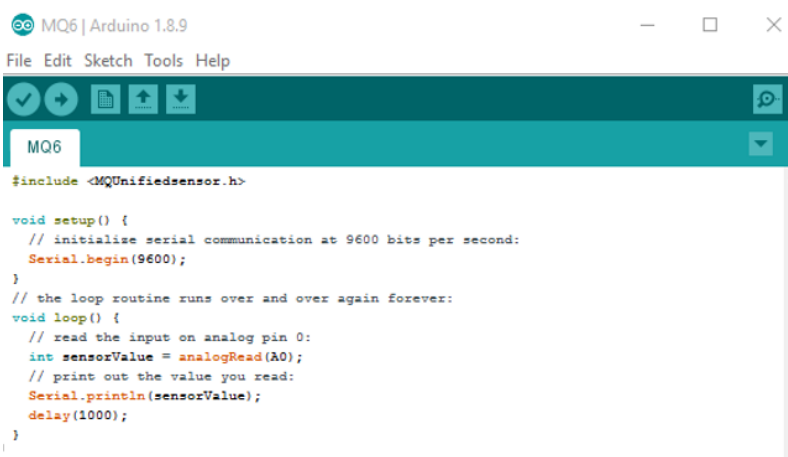

Gbr 6. Program arduino dengan sesor gas MQ-6.

Gambar di bawah ini adalah nilai pada serial monitor saat tidak terdeteksi adanya gas LPG pada udara. Lalu saat gas LPG terdeteksi dalam kandungan udara nilai di atas akan meningkat, hal ini yang nantinya dipergunakan dalam menentukan titik kerja alat deteksi kebocoran gas LPG. 


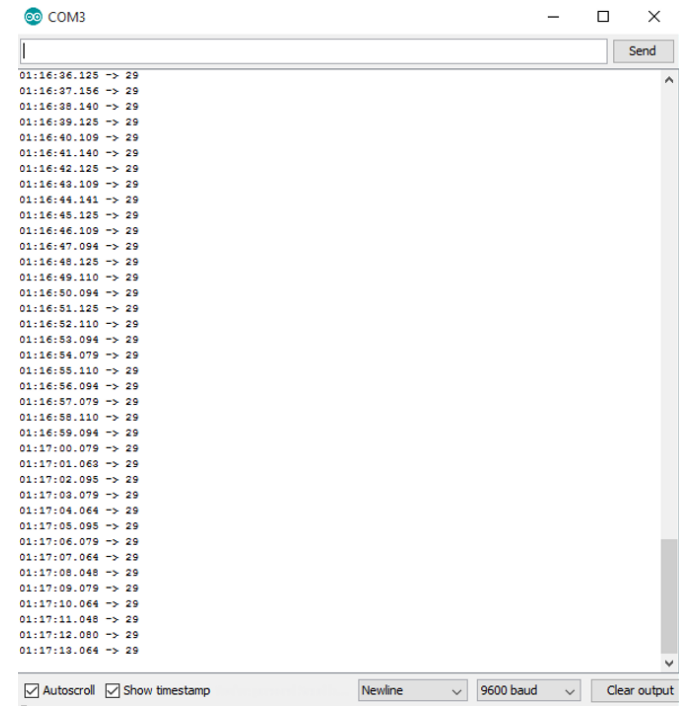

Gbr 7. Pembacaan nilai pada serial monitor tanpa adanya gas LPG terdeteksi.

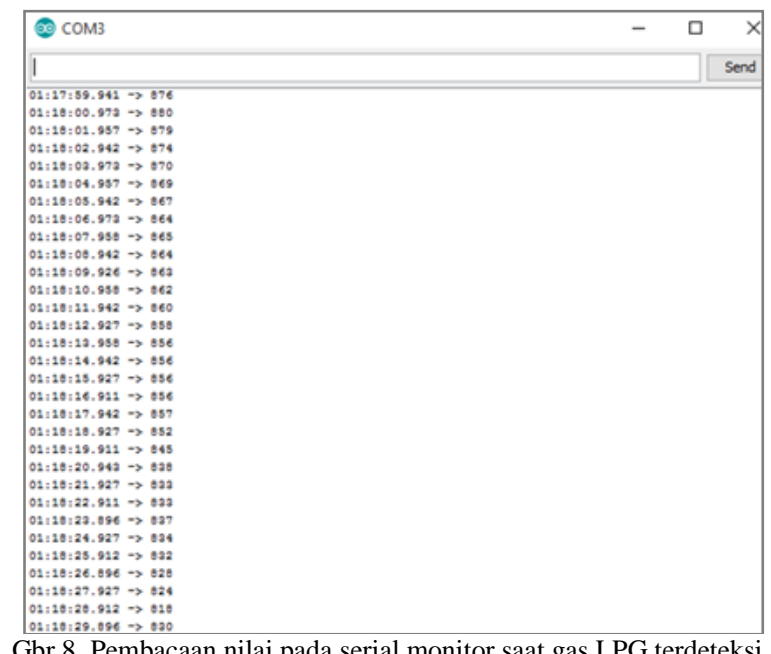

Nilai berbeda ditunjukkan pada hasil pembacaan pada aplikasi Blynk. Dalam tahap ini, dilakukan sinkronisasi antara nodemcu ESP8266 dengan aplikasi Blynk terlebih dahulu. Berikut kode yang diberikan pada nodemcu ESP8266.

Dimana nilai terendah pembacaan saat tidak terdeteksi gas LPG adalah 195 dan nilai tertinggi saat terdeteksi gas LPG adalah 1024. Maka didapatkan aktivasi kerja alat saat nilai pada analog output sensor kurang dari 500 nodemcu ESP8266 akan bekerja memberikan perintah untuk menghentikan bunyi alarm (buzzer) dan mematikan lampu led merah, mengaktifkan lampu led hijau sebagai tanda tidak ada gas dalam ruangan.

Apabila nilai analog sensor $>500$, sensor akan mengirimkan sinyal ke nodemcu ESP8266 dan arduino membunyikan alarm (buzzer), menyalakan lampu led merah sebagai tanda ada gas dalam ruangan dan memberikan notifikasi kebocoran gas. Dimana notifikasi akan dikirimkan berdasarkan pesan yang telah diatur pada aplikasi Blynk.
Pada Blynk, nilai terendah pembacaan saat tidak terdeteksi gas LPG adalah 195 dan nilai tertinggi saat terdeteksi gas LPG adalah 1024
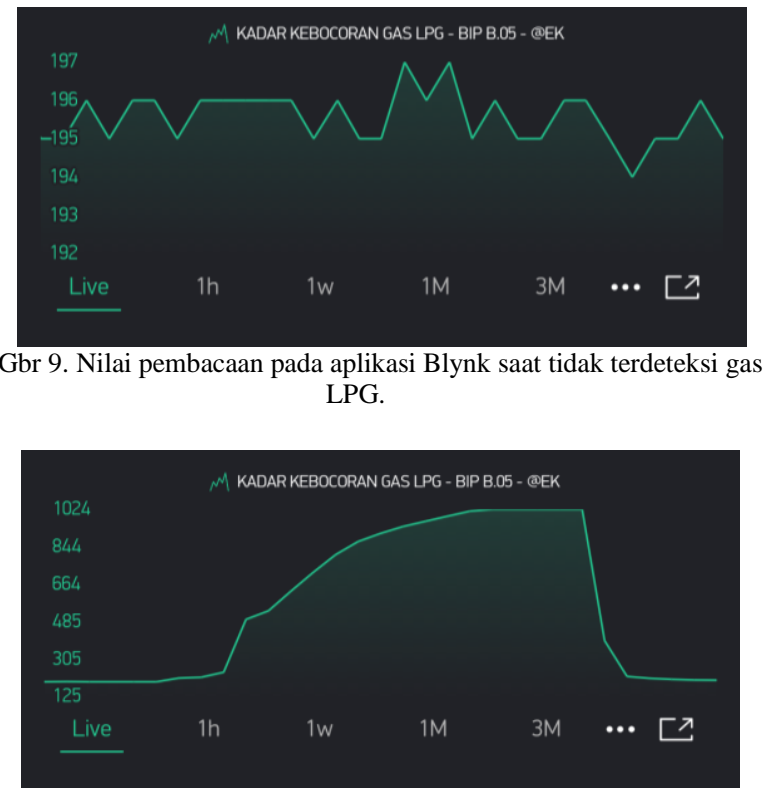

Gbr 10. Nilai pembacaan pada aplikasi Blynk saat terdeteksi gas LPG

Berdasarkan hal diatas maka didapatkan aktivasi kerja alat saat nilai pada analog output sensor kurang dari 500 nodemcu ESP8266 akan bekerja memberikan perintah untuk menghentikan bunyi alarm (buzzer) dan mematikan lampu led merah, mengaktifkan lampu led hijau sebagai tanda tidak ada gas dalam ruangan.

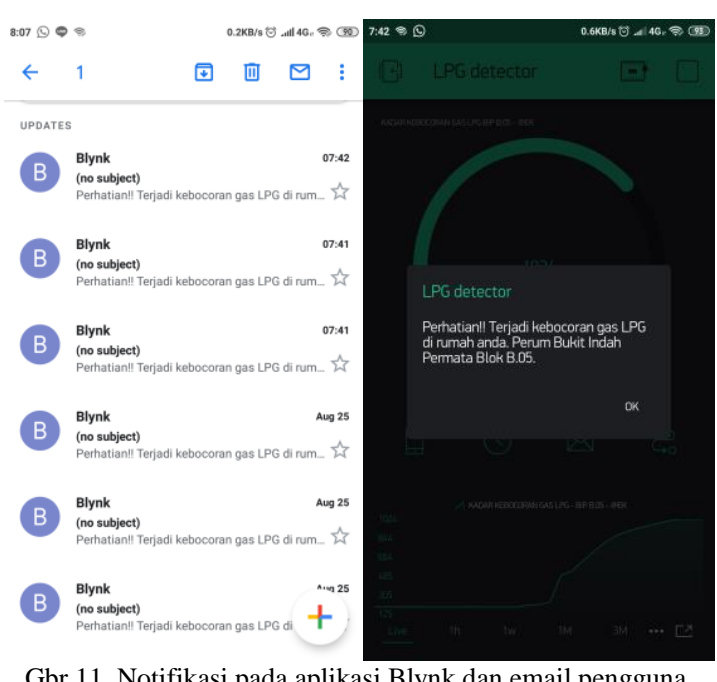

Apabila nilai analog sensor $>500$, sensor akan mengirimkan sinyal ke nodemcu ESP8266 dan arduino membunyikan alarm (buzzer), menyalakan lampu led merah sebagai tanda ada gas dalam ruangan dan memberikan notifikasi kebocoran gas. Dimana notifikasi akan dikirimkan berdasarkan pesan yang telah diatur pada aplikasi Blynk. 
Pada alat detektor gas ini dilengkapi dengan lampu led dan buzzer. Yang digunakan sebagai indikator gas yang terdeteksi oleh sensor. Dalam sistem kerjanya lampu led dan buzzer ini bekerja berdasarkan gas yang terdeteksi Sedangkan untuk buzzer digunakan sebagai indikator alarm apabila terdeteksi gas, yang mana dalam perancangannya sebagai penanda alarm akan terus berbunyi hingga kadar gas kembali normal diikuti lampu LED berwarna hijau. Berikut adalah tabel kerja led dan buzzer.

TABEL II

OPERASI KERJA RGB LED DAN BUZZER

\begin{tabular}{|c|c|c|}
\hline No & Nilai pada Blynk & Operasi \\
\hline 1 & $<500$ & $\begin{array}{c}\text { RGB Led menyala hijau } \\
\text { Buzzer tidak aktif }\end{array}$ \\
\hline 2 & $>500$ & $\begin{array}{c}\text { RGB Led menyala merah } \\
\text { Buzzer aktif }\end{array}$ \\
\hline
\end{tabular}

Tahapan berikutnya adalah pengujian respon dari alat dalam mendeteksi kebocoran. Hal ini dilakukan dengan menempatkan sumber kebocoran gas pada jarak tertentu dari sensor. Berikut tabel hasil yang didapatkan:

TABEL III : WAKTU PENDETEKSIAN BERDASARKAN JARAK DAN KONDISI RUANG

\begin{tabular}{|c|c|c|c|}
\hline No & $\begin{array}{c}\text { Jarak Alat dengan } \\
\text { Sumber Kebocoran }\end{array}$ & Rentang Waktu Deteksi & Kondisi Ruang \\
\hline 1 & $5 \mathrm{~cm}$ & 3 detik & Tertutup \\
\hline 2 & $5 \mathrm{~cm}$ & 5 detik & Terbuka \\
\hline 3 & $10 \mathrm{~cm}$ & 7 detik & Tertutup \\
\hline 4 & $10 \mathrm{~cm}$ & 15 detik & Terbuka \\
\hline 5 & $15 \mathrm{~cm}$ & 10 detik & Tertutup \\
\hline 6 & $15 \mathrm{~cm}$ & Tak terdeteksi & Terbuka \\
\hline 7 & $20 \mathrm{~cm}$ & 13 detik & Tertutup \\
\hline 8 & $20 \mathrm{~cm}$ & Tak terdeteksi & Terbuka \\
\hline 9 & $25 \mathrm{~cm}$ & 17 detik & Tertutup \\
\hline 10 & $25 \mathrm{~cm}$ & Tak terdeteksi & Terbuka \\
\hline
\end{tabular}

Dari tabel diatas menunjukkan bahwa waktu deteksi pada sensor MQ-6 akan bergantung pada jarak sensor dengan sumber kebocoran dan kondisi ruang. Alat pendeteksi akan bekerja lebih efektif pada ruang tertutup dimana kadar gas tidak mudah berkurang dalam udara. Jarak gas sensor dari sumber kebocoran dengan rentang waktu deteksi akan berbanding lurus.

\section{Kesimpulan}

Dari penelitian ini kebocoran tabung LPG yang terjadi di rumah tangga dapat dideteksi dengan alat pendeteksi kebocoran berbasis arduino uno dan dapat diaplikasikan di masyarakat. Alat ini dibuat dengan mengintegrasikan arduino uno R3 dengan sensor gas MQ-6 dimana dalam operasinya.

komponen penunjang lain seperti RGB LED dan buzzer juga dipergunakan untuk mencegah potensi pemicu kebakaran.
Sistem pengawasannya pun dapat dikembangkan melalui aplikasi Blynk pada smartphone pengguna dengan penggunaan nodemcu ESP8266 sehingga hal ini sesuai dengan kaidah Internet of thing.

Alat pendeteksi kebocoran gas ini dibuat dengan menggunakan sensor yang hanya 1 buah. Oleh karena itu pengembangan alat ini bisa saja dengan menambahkan jumlah sensor gas LPG yang lebih dari 1. Sehingga jika ada suatu ruangan yang bocor bisa dideteksi dengan alat ini dengan tingkat sensitivitas yang lebih baik.

\section{REFERENSI}

[1] I. Kurniaty and H. Hermansyah, "POTENSI PEMANFAATAN LPG (LIQUEFIED PETROLEUM GAS) SEBAGAI BAHAN BAKAR BAGI PENGGUNA KENDARAAN BERMOTOR,' pp. 2-3, 2016.

[2] PT Safety Sign Indonesia, "https://safetysign.co.id," PT Safety Sign Indonesia, 27 October 2015. [Online]. Available: https://safetysign.co.id/news/179/PenyebabKebakaran-LPG-dan-Cara-Mengatasinya/. [Accessed 15 May 2019].

[3] Pertamina, “pertamina.com,” energia-news, 13 Januari 2014. [Online]. Available:

https://www.pertamina.com/id/viewarchive/energianews/seluk-beluk-lpg-di-indonesia. [Accessed 1 Juni 2019].

[4] Wikipedia, “wikipedia.org," 24 Desember 2010. [Online]. Available:

https://id.wikipedia.org/wiki/Arduino. [Accessed 1 Juni 2019].

[5] Suhendri, "belajardasar-pemrograman.blogspot.com," Maret 2013. [Online]. Available: http://belajar-dasarpemrograman.blogspot.com/2013/03/arduino-uno.html. [Accessed 2 Juni 2019].

[6] H. Sirait, "Desain Alat Pendeteksi Kebocoran Gas LPG Menggunakan Sensor MQ-6 Berbasis ATmega8," SP Metrologi dan Instrumentasi, pp. 4-8, 2017.

[7] REXUSID, “REXUS,” 31 January 2018. [Online]. Available: https://rexus.id/apa-itu-led-rgb-dalamkeyboard-mekanikal/. [Accessed 1 Juni 2019].

[8] B. D. Danur, D. Satria and R. Aisuwarya, "Sistem Pendeteksi Kebocoran Gas LPG Menggunakan Mikrokontroller," E-Journal Universitas Andalas, pp. 115, 2009.

[9] F. Azzam and A. Nurhayati, "Rancang Bangun Sistem Komunikasi Dua Arah Antara Tamu dan Pemilik Rumah Menggunakan Sensor Getar dan Modul GSM," Jurnal ICT Akademi Telkom Jakarta, vol. IX, pp. 2-3, 2018.

[10] sinauarduino, "sinauarduino," 6 April 2016. [Online]. Available: 
http://www.sinauarduino.com/artikel/esp8266/. [Accessed 5 Juni 2019].

[11] Espressif Systems IOT Team, “adafruit,” 1 Juni 2015. [Online]. Available: https://cdn-

shop.adafruit.com/product-files/2471/0A-

ESP8266_Datasheet_EN_v4.3.pdf. [Accessed 5 Juni 2019].

[12] M. Burgess, "wired," 16 February 2018. [Online]. Available: https://www.wired.co.uk/article/internet-ofthings-what-is-explained-iot. [Accessed 5 Juni 2019].
[13] A. Faudin, "Nyebarilmu," 23 November 2017. [Online]. Available: https://www.nyebarilmu.com/mengenalaplikasi-blynk-untuk-fungsi-iot/. [Accessed 5 Juni 2019]. 